\title{
Training as Mediating in the Relationship Between Organization Reward and Employee Motivation
}

\author{
Muhammad Asif Khan \\ School of Management \\ Huazhong University of science and technology Wuhan \\ Hubei People's Republic of China \\ Asif marwat1439@yahoo.com \\ Asima Siddique \\ Department of Management Science, \\ COMSATS University Islamabad Pakistan \\ asimasiddique76@gmail.com \\ Zahid Sarwar \\ School of Business Administration, \\ Dongbei University of Finance and Economics \\ Dalian, Liaoning, $C N$ \\ zahidsarwar13@gmail.com
}

\begin{abstract}
Training and organization rewards plays important role in the development and motivation of the employees. And organization gives more attention to reward and training programs to motivate their employees. The purpose of this paper is to examine the relationship in between rewards and employees motivation. In addition the paper also aims to measure the mediating role of training.Employee'sidea and perception about organizational rewards and its impact on employee's motivation have been evaluated empirically with the sample of 173 employees in district account offices. The data have been collected from the employees using survey method. SPSS have beenused to analyze the data the results show the mediating effect of training on the relationship between organization rewards and employee's motivation. The results show that both training and organizational rewards have positive association with employee's motivation. The study will help the administration of district account offices to develop policy that will cope with the challenges and difficulties in training and rewards management. And it will help in employee's motivation.
\end{abstract}

Key words. Organization rewards (OR), employee's motivation (EM), training (TR), District account offices, Pakistan.

\section{1: Introduction}

Employees play an important role in the growth and expansion of the organization and society. The development of the organization can be achieved only through strong workers, professional workers, well trained and managed employees. The skills and ability of the employees play key role in the success of the organizations (saetang, salumnad, Thampitak, sungkaew, 2010). As 
researchers know that it's more competitive world and every organization try to become better than other organization. So it is the main objective of the organizations to do best to become unique in the market according to employees needs and environmental changes. So the management of the organization should make plans and strategies according the working environment and employee's motivation. So the management of the organization have a lot of responsibilities to expand these relationship to act strongly to give unique position in the society. Inspired staff is vital for the productive action of someprivate, government, minor and big sections of any association. Motivation is the accessibility and enthusiasm of an employee to move up with his obligation (Robbins, Odendaal, \&Roodt, 2003). If the employees are pleased with their action and feel safe and secure with the overall practices and procedure for allowing rewards, it is truthfully noticeable that they will be extremely active and will do great work according to requirements for the administration.

Training and reward are necessary for the enhancement of workers motivation. Now it is compulsory to know that which kind of part training plays important role in reward and motivation of employees. It will discover the association in between organization rewards and employees motivation with the mediating role of training. This study will tell us how much the employees of different account offices is affected by rewards policy. And training plays mediating role in organization rewards and employees motivation. This study will help out how top level management can use their organization rewards and their training facility to enhance the employee's motivation. The specified objective are: to identify the relationship between the independent variables and dependent variable. To evaluate the impact of training as mediator between employee motivation and rewards. To confirm the reliability of worker motivation by rewards and training.

\section{Literature review}

Muga et Al (2018) studied the relationship in between financial rewards and employees motivation and concluded that financial rewards have significant impact upon the workers in commercial of Kenya and give recommendations that organizations must give rewards system to the employees to motivate and encourage them to work very hard. According to Mcload (2015) punishment is the procedure that's weakens the behavior and stops the individual to stop its repetition. So punishment decreases that behavior of the employees which is harmful for the organization and affects the individual performances. Organization can use both financial and non-financial awards as a positive tool to strengthen the act extra effort among the workers and that will be beneficial for the organization (Sammons, 2012). So this theory supports that monetary awards will motivate the employees to better for the organization.

Rewards may be defined as all types of financial returns, benefits and other things that are employees received as upon relationship with the employment (Edirisooriya, 2014). According to Rizwan and ali (2010) the operative appreciation and prizesare appreciated inside an institute, as an outcome, betterworking atmosphere is attained which influence employees to top opportunities in their performance. Lotta (2012) emphasized that financial incentives are unbelievable in increasing confidence of employees. Moreover, Ojokuku and Sajuyigbe (2009) stated that monetary inspiration have important result on agent's performance and motivation. Reward is the most significant component to eradicate employee for compensating their greatest hard work to make the innovation and the new philosophies in cress the company performance monetary and non-monetary Dewhurst et al (2010) association of the manager controller, reward power positivity related with worker performance more production satisfaction and turnover and society 
social responsibility conduct (Simon, 1976; more hunt 1980; Jahangir, 2006). Murphy (2015) concluded that financial rewards in very important in managing employee's performance because rewards can motivate the employees to perform specific task and function. Rewards can be specified to teams and group of peoples to achieve agreed goals. The package supposes to increase the concluding profit of institute by conceiving the welfares of employees and the corporation's rewards and financial profit (Jaw, 2010). Markova and Ford (2011) specified that the achievement of the administrative mostly rest on upon workers eager to practice their attention, aptitude, skills and inventiveness in the courtesy of the association and the association is obligatory to usage this worker very healthy and inspire them and declares the price and remuneration for their good effort and work.

\subsection{Employee Motivation}

Creech (1995) stated that "motivation is that offers influence to our behavior by thrilling, supporting, encouraging and supervisory it toward the achievement of goals and objective. Inspiration is besides essential once the human capital hasn't reputable affiliation structure. Labors relationship with managers and others officer is an important constituent of the inside nature of the association. The extremely motivated worker builds benefits for their enterprise and leads the organizations towards its goals (Rizal and ali, 2010). Motivation and inspiring as well as the will of employees to consume their power in an exact manner to achieve specific objectives (Edmonstone, 1996). According to Armstrong (2012) observed that motivation is an influence that excites, organizes, stays conduct. That is concerned almost about the quality and behavior of manner, and the mechanisms that effect persons to do in confident methods. Malhotra et al. (2007) represent rewards as 'all types of money correlated return, clear groups and liking a worker becomes as a notable part of a professional relationship'. Administrators predict that representatives will pass on or perform committed promises attractive to them while authorities in like way to predict that their bosses will promise them of pleasant salaries and pay rates (rewards) later they passively permit on what is predicted from employees (Eshun and Duah, 2011).

\subsection{The Relationship between Financial reward and motivation}

Cash connected stimuli similarly increase the confidence of the labor force, and favors for these prizes and rewards are particularly widespread in relations, mainly in the current assessment of the implementation of globalization and development (Appelbaum et al., 2011; Datta, 2012). Those awards that are connected to money are excluded from business such as advance, bonus, salaries and other financial benefits. Models known as distinctive models are wages increment, wages and salaries rates and around about cross establishments shapes at time of paying (Mahaney and Lederer, 2006; Mottaz, 1985). Monitory awards are connected each other frequently showing that they are closely related to the tasks performed. Cash is used as the award to be paid to the employees as motivation factor

\subsection{The Association between Non-financial rewards and employees motivation}

Rewards not only consists of cash related rewards but it consists of different things such as greeting, high status in the organizations, commitments, apperceptions, encourages the employees to do well, motivate them is one of the most important non-monetary rewards that have great importance for administrations. So that the way, being treated well and the bosses that help the workforce and cheering workforce will remain with the directors for ever(Frey, 1997).Normal motivation and inspiration from persons or their development can effect implementation and prosperous (Ryan \&Deci, 2000). 
The increments related to cash and to which level it will be given, non-cash awards have a similar strong associations. The administration must be motivated and inspired be normal awards and prizes. For example by strong and clear message about award and motivation will give the helpful and gainful results. Irrespective both monetary and non-monetary awards involves administrations to have more prominent execution, implementation and productivity (Reio and Callahon, 2004).Feelings switch the unbelievable practices of authorities with depressed or enjoyment. Administrations likewise permit an individual person to accumulate responsive interplanetary for situations and final objective and products

\subsection{Training}

According to Krueger \& Rouse (1998) revealed that elementary skills and training and precise abilities are often stationary with one another. They revealed that employees that go through to training, of their specificity irrespective, became more keen labors. These employees were established to follow additional job expansions, get extra performance good, awards, and too have better job existence than those employees that does not go to training programs.

Glance, Hogg, and Huberman (1997) recognized these declarations to be suitable in their study that observed both training and income awards from the point of interpretation of rising establishments. And they concluded that training supports in many organization in long term run. That is in fast running to make position in the market the teamwork can be achieved through giving different training programs that would decrease the need and requirement of combine organization events.

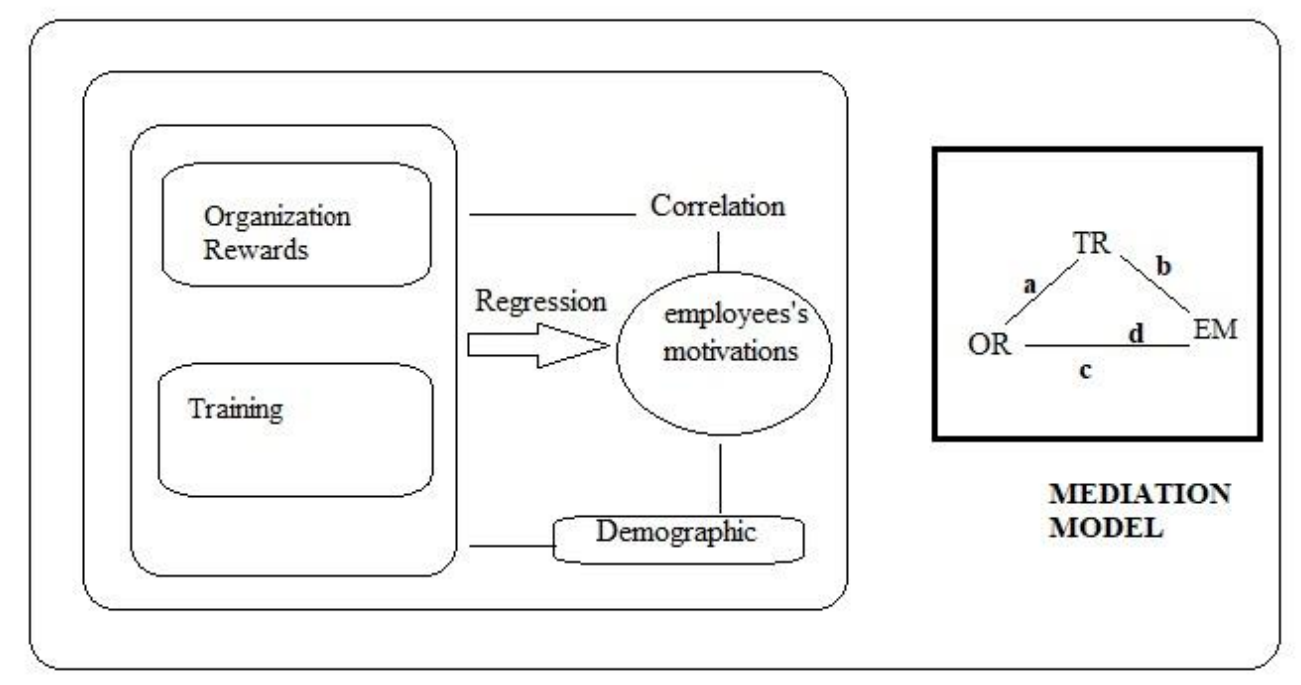

FRAMEWORK 


\subsection{Data methodology}

This study is conducted to find out the mediating role of training in between employee's motivation and organizations rewards. The data is collected from different employees working in the different account offices of Khyber Pakhtunkhwa, Pakistan.

\subsection{Reliability of questionnaire}

To check the reliability of questionnaire the Cronbach's test is done. The results show that the cronbach's alpha is 0.84 which is quite good, so we can say that our questionnaire is reliable.

\subsection{Frequency statistics}

To know the details about different demographic the frequency techniques is done which is given for each demographic given below

Total number of respondents 173

\begin{tabular}{ccccc}
\hline Profile & Frequency & Percent & Valid Percent & $\begin{array}{c}\text { Cumulative } \\
\text { Percent }\end{array}$ \\
\hline Gender & & & & \\
male & 148 & 85.5 & 85.5 & 85.5 \\
female & 25 & 14.5 & 14.5 & 100.0 \\
$\begin{array}{c}\text { Education } \\
\text { under graduate }\end{array}$ & 66 & 38.2 & 38.2 & 38.2 \\
graduate or over & 107 & 61.8 & 61.8 & 100.0 \\
$\begin{array}{c}\text { Position } \\
\text { staff }\end{array}$ & 122 & 70.5 & 70.5 & 70.5 \\
$\begin{array}{c}\text { officer } \\
\text { Experience }\end{array}$ & 51 & 29.5 & 29.5 & 100.0 \\
$\begin{array}{c}\text { less than } 10 \\
\text { year }\end{array}$ & 128 & 74.0 & & \\
over than 10 & & & 74.0 & 74.0 \\
year & 45 & 26.0 & 26.0 & 100.0 \\
Domicile & & & & \\
local & 140 & 80.9 & 80.9 & 80.9 \\
non local & 33 & 19.1 & 19.1 & 100.0 \\
\hline
\end{tabular}

The above table shows that out of 173 employees the male employees are 148 and female employees are 25 showing that male are working more in account offices as compare to female. The qualification statistics shows that 66 employees have the qualification of less than fourteen years of schooling and 107 employees have qualification for than 14 years of schooling. The frequency shows that out of 173 employees the 122 employees are in general staff position while 51 employees are in officer rank with the valid percent of 70.5 and 29.5 respectively. The above table shows that out of 173 employees the 128 employees have less than 10 year of experience while only 45 employees have more than ten year of experience. As we know that people are more interested to work at their birth places so above table proves that. Out of 173 employees 140 employees are belong to local areas where only 33 employees are belonging to other than local's areas. 


\subsection{Descriptive statistics}

To know the nature of the data, descriptive statistics is done and the results are given below

Descriptive Statistics

\begin{tabular}{|c|c|c|c|c|c|c|}
\hline & $\mathrm{N}$ & Minimum & Maximum & Mean & Std. Deviation & Variance \\
\hline Org rewards & 173 & 1.00 & 5.00 & 3.2145 & .88473 & .783 \\
\hline Training & 173 & 1.60 & 4.50 & 3.0301 & .60638 & .368 \\
\hline Emp motivation & 173 & 2.80 & 5.00 & 4.0387 & .48687 & .237 \\
\hline Valid N (listwise) & 173 & & & & & \\
\hline
\end{tabular}

The descriptive statisticsshows that means value for employees motivation is more as compare to other two variables. The standard deviation and variance is more for organization rewards as compare to other to variables. The total number of observation is 173 .

\subsection{Correlation analysis}

The correlation matrix is given below to know the association between different variables. The Pearson correlation is done which is given below

\begin{tabular}{|c|c|c|c|c|}
\hline & & Org rewards & training & Emp motivation \\
\hline \multirow[t]{3}{*}{$\begin{array}{c}\text { Org } \\
\text { rewards }\end{array}$} & $\begin{array}{l}\text { Pearson } \\
\text { Correlation }\end{array}$ & 1 & $.238^{* *}$ & $.228^{* *}$ \\
\hline & Sig. (2-tailed) & & .002 & .003 \\
\hline & $\mathrm{N}$ & 173 & 173 & 173 \\
\hline \multirow[t]{3}{*}{ Training } & $\begin{array}{l}\text { Pearson } \\
\text { Correlation }\end{array}$ & $.238^{* *}$ & 1 & $.201^{* *}$ \\
\hline & Sig. (2-tailed) & .002 & & .008 \\
\hline & $\mathrm{N}$ & 173 & 173 & 173 \\
\hline \multirow[t]{3}{*}{ Empmoti } & $\begin{array}{l}\text { Pearson } \\
\text { Correlation }\end{array}$ & $.228^{* * *}$ & $.201^{* *}$ & 1 \\
\hline & Sig. (2-tailed) & .003 & .008 & \\
\hline & $\mathrm{N}$ & 173 & 173 & 173 \\
\hline
\end{tabular}

**. Correlation is significant at the 0.01 level (2-tailed).

The table shows that correlation between training and organization rewards are $.238^{* *}$ and correlation between organizational rewards and employees motivation are $.228^{* *}$. And in between training and employees motivation the correlation is $.201^{* *}$. So from above correlation matrix it's concluded that all the variables are significantly correlated with each other.

\subsection{Regression and mediation analysis}

In order to find out the impact of variables upon dependent variables the regression analysis is done and mediation analysis is done to know the mediating role of training in between the dependent variable and independent variable. 
Step one A (OR-TR)

Coefficient of regression between organization rewards and training

\begin{tabular}{|c|c|c|c|c|c|c|}
\hline & \multirow[b]{2}{*}{ Model } & \multicolumn{2}{|c|}{$\begin{array}{l}\text { Unstandardized } \\
\text { Coefficients }\end{array}$} & \multirow{2}{*}{$\begin{array}{c}\text { Standardized } \\
\text { Coefficients } \\
\text { Beta }\end{array}$} & \multirow[b]{2}{*}{$\mathrm{t}$} & \multirow[b]{2}{*}{ Sig. } \\
\hline & & B & Std. Error & & & \\
\hline \multirow[t]{2}{*}{1} & (Constant) & 2.506 & .170 & & 14.767 & .000 \\
\hline & $\begin{array}{c}\text { Org } \\
\text { rewards }\end{array}$ & .163 & .051 & .238 & 3.203 & .002 \\
\hline
\end{tabular}

a. Dependent Variable: training

In step one organization rewards is regressed over training the outcomes showed that organization reward is significant to training so it have positive impact upon each other.

Step twoB (TR-EM)

Coefficient of regression between training and employee's motivation

\begin{tabular}{ccccccc}
\hline \multicolumn{7}{c}{ Unstandardized } \\
Coefficients & \multicolumn{2}{c}{$\begin{array}{c}\text { Standardized } \\
\text { Coefficients }\end{array}$} \\
& Model & $\mathrm{B}$ & Std. Error & Beta & $\mathrm{t}$ & Sig. \\
\hline 1 & (Constant) & 3.549 & .186 & & 19.099 & .000 \\
& training & .162 & .060 & .201 & 2.686 & .008 \\
\hline
\end{tabular}

a. Dependent Variable: emp mot

In step we regress the employee's motivation and training and find out training have positive impact upon employee's motivation because the significance value for training on employees motivation.

Step three C (OR-EM)

Coefficient of regression between organization rewards and employee's motivation

\begin{tabular}{|c|c|c|c|c|c|c|}
\hline & \multirow[b]{2}{*}{ Model } & \multicolumn{2}{|c|}{$\begin{array}{l}\text { Unstandardized } \\
\text { Coefficients }\end{array}$} & \multirow{2}{*}{$\begin{array}{c}\text { Standardized } \\
\text { Coefficients } \\
\text { Beta }\end{array}$} & \multirow[b]{2}{*}{$\mathrm{t}$} & \multirow[b]{2}{*}{ Sig. } \\
\hline & & B & Std. Error & & & \\
\hline \multirow[t]{2}{*}{1} & (Constant) & 3.635 & .137 & & 26.617 & .000 \\
\hline & $\begin{array}{l}\text { Org } \\
\text { rewards }\end{array}$ & .126 & .041 & .228 & 3.064 & .003 \\
\hline
\end{tabular}

a. Dependent Variable: Emp mot

The above steps showing regression in between organization rewards and employee's motivation and results showing that it is positively associated in between them so organization rewards impact the employee's motivation in positive way. 
Overall modelD (OR, TR - EM)

Coefficient of regression model

\begin{tabular}{|c|c|c|c|c|c|c|}
\hline & \multirow[b]{2}{*}{ Model } & \multicolumn{2}{|c|}{$\begin{array}{l}\text { Unstandardized } \\
\text { Coefficients }\end{array}$} & \multirow{2}{*}{$\begin{array}{c}\text { Standardized } \\
\text { Coefficients } \\
\text { Beta }\end{array}$} & \multirow[b]{2}{*}{$\mathrm{t}$} & \multirow[b]{2}{*}{ Sig. } \\
\hline & & B & Std. Error & & & \\
\hline \multirow[t]{3}{*}{1} & (Constant) & 3.322 & .204 & & 16.275 & .000 \\
\hline & training & .125 & .061 & .156 & 2.051 & .042 \\
\hline & $\begin{array}{c}\text { Org } \\
\text { rewards }\end{array}$ & .105 & .042 & .191 & 2.516 & .013 \\
\hline
\end{tabular}

a. Dependent Variable: Emp mot

The above table shows the results in between organization rewards, and training on employee's motivation. The results showing that both the independent variables are significant impact upon dependent variables. The significant value for training is .042 and for organization rewards its value is .013 so from the final results we concluded that it have positive and significant impact upon employee's motivation. Also from above result we concluded that one percent change in training will increase the employee's motivation by 12.5 percent and similarly the change in organization rewards will effect by 10.5 percent so we can say that training plays more role in employee's motivation as compare to organization rewards.

\subsection{Mediation results}

In order to know the mediation effect of training in between organization rewards and employee's motivation. The below table will gives details of mediation effect

\begin{tabular}{|c|c|c|c|}
\hline Model & Variables & Results & Remarks \\
\hline 1 & {$[\mathrm{IV}-\mathrm{MV}]$} & $\mathrm{B}=.163, \mathrm{P}=.002$ & Significant impact \\
\hline & {$[\mathrm{M}$} & $B=.16$ & Significant impact \\
\hline 3 & {$[\mathrm{IV}-\mathrm{DV}]$} & $\mathrm{B}=.126, \mathrm{P}=.003$ & Significant impact \\
\hline \multirow[t]{2}{*}{ Final } & [IV-MV-DV] & $\mathrm{B}=.125, \mathrm{P}=.042$ & Significant impact \\
\hline & & $\mathrm{B}=.105, \mathrm{P}=.013$ & Significant impact \\
\hline
\end{tabular}

The above table shows that the training is playing mediating role in between organization rewards and employees motivation so we conclude that training have impact in between rewards and motivation. The above tables also showing that all the models are significant and positively associated with each other.

\subsection{Findings}

The gender frequency tables shows that out 173 respondents the number of male respondent are 85.5 percent and female respondent are 14.5 percent which shows that In account offices of Khyber Pakhtunkhwa (KPK) Pakistan the male are working more as compare to female. While the education table showing that number of respondent having fourteen year of schooling or more is $61.8 \%$ while respondents having less than fourteen year of schooling are $38.2 \%$ which showing that more educated people are working in account offices of KPK. The position table showing that officer percent is 29.5 while staff percent is 70.5 percent which shows many reasons such as long promotion policy and secondly more staff is required in these offices as compare to officer that why it is in less in number. While the experience frequency tables showed that respondents having less than ten year experience is 74.0 percent and more than ten year 
experience have 26 percent which shows that more people are hired in last ten years. And the local frequency table showing that more respondents belong to local area as compare to nonlocal. The frequency of local is 80.9 while non-local is 19.1 percent. The results showed that all the variables are positively correlated with each other. The correlation between organization rewards and employees motivation is $.228^{* *}$ which showed that changed in one variable can affect the other variable by 23 percent. And the correlation between organization rewards and training is $.238^{* *}$. From this we find out the training can influence the organization by 24 percent. Similarly correlation between training and employees motivation are $.201^{* *}$ so these variables influence each other by 20 percent.

Regression analysis is done in between dependent and independent variables and all the models show that all the variables are positive relationship with each other. In final model showed that both the organization rewards and employees motivation have positive impact upon employees motivation. The $\mathrm{p}$ value for both training and organization rewards are .042 and .013 respectively which is below the 5 percent level so we conclude that these variables have influence upon employs motivation. From the different models we run showed that training is playing mediating role in between organization rewards and employees motivation because it increase the motivation and efficiency of the employees.

\subsection{Conclusion}

This study focused on analyzing the impact of training as a mediating role in between organization rewards and employee's motivation and we conclude that both organization rewards and training are playing key role in employee's motivation as proved from the results above. No one can say that rewards is not important for employee's motivation. Behrman and Perreault (1982) working on worker mental level and how they are working with different environment they said that each type of rewards have their own importance and should be consider to make organization successful and organization success depends upon different things such as capital resources, natural resources and human resources. The organization that gives more rewards and training leads to success so it the duty of the organization to give more rewards and training to employees to compete and to work better and to help the organization to achieve its goals.

\subsection{Recommendations}

$\checkmark$ The main aim and goal of the organization is to increase the performance of the employees. And this can be done only through motivation so rewards and trainings can boost the employee's motivation which will increase the employee's performance.

$\checkmark$ More training program should be given to employees.

$\checkmark$ Effective award policy should be developed that encourage the employees.

$\checkmark$ Timely promotion policy should be adopted.

$\checkmark$ Government should encourage female to work in this type of organization.

$\checkmark$ Salaries, awards and bonus should be given to employees regularly this will increase the employees motivation to do more and more better work for the organization.

\subsection{Limitation and Future study}

There are some limitations in this empirical study. First of all the study, this study only investigates the specific organization ( accounts offices). Secondly in this study the data is only collected from Khyber Pakhtunkhwa (Pakistan) which may limit the generalization of results of this study. Future study can be conducted in any other organization to generalize the results and to modify the concepts. 


\section{References}

Ajila, C.O. (1997). Job motivation and attitude to work as correlates of productivity among workers in manufacturing companies in Lagos State, Nigeria. Unpublished PhD Dissertation). OAU Ile-Ife Osun State, Nigeria.

Armstrong, M. C. \& Murlis, H. (2004). Reward management. Kogan Page.

Castro, M. L. \& Martins, N. (2010). The relationship between organizational climate and employee satisfaction in a South African information and technology organization. SA Journal of Industrial Psychology, 36(1), pp.1-9.

Creech, R. (1995). Employee motivation. Management Quarterly, 36(2), p.33.

Edirisooriyaa, W. A. (2014). Impact of rewards on employee performance: With special reference to ElectriCo. In Proceedings of the 3rd International Conference on Management and Economics, Vol. 26, p. 27.

Edmonstone, J. (1996). Appraising the state of performance appraisal. Health Manpower Management, 22(6), pp.9-13.

Eshun, F.K.D. (2011). Rewards as a Motivation tool for Employee Performance.

Fagnani, S., \& Media, D. (2016). Why Is Operant Conditioning Useful in theWorkplace?

Frey, B.S. (1997). Not just for the money (Vol. 748). Cheltenham: edwardelgar.

Grimsley, S. (2016). Reinforcement Theory in the Workplace: Definition \& Examples.

Glance, N.S., Hogg, T. \& Huberman, B.A., (1997). Training and turnover in the evolution of organizations. Organization Science, 8(1), pp.84-96.

Guest, D.E. (2011). Human resource management and performance: still searching for some answers. Human resource management journal, 21(1), pp.3-13.

Hameed, A., Ramzan, M. \& Zubair, H. M. K. (2014).Impact of compensation on employee performance (empirical evidence from banking sector of Pakistan). International Journal of Business and Social Science, 5(2).

Jaw, C., Lo, J. Y. \& Lin, Y.H. (2010). The determinants of new service development: Service characteristics, market orientation, and actualizing innovation effort. Technovation, 30(4), pp.265-277.

Kreisman, B.J. (2002). Insights into employee motivation, commitment and retention. Business Training Experts: Leadership Journal, pp.1-24.

Krueger, A. \& Rouse, C. (1998).The effect of workplace education on earnings, turnover, and job performance. Journal of labor economics, 16(1), pp.61-94.

Lazazzara, A. \& Bombelli, M. C. (2011). HRM practices for an ageing Italian workforce: the role of training. Journal of European Industrial Training, 35(8), pp.808-825.

Mahaney, R.C. \& Lederer, A. L. (2006).The effect of intrinsic and extrinsic rewards for developers on information systems project success. Project Management Journal, 37(4), pp.4254.

Malhotra, A., Majchrzak, A. \& Rosen, B., (2007).Leading virtual teams. Academy of Management perspectives, 21(1), pp.60-70.

Markova, G. \& Ford, C. (2011). Is money the panacea? Rewards for knowledge workers. International Journal of Productivity and Performance Management, 60(8), pp.813-823. McArthur, L.Z. \& Baron, R.M. (1983).Toward an ecological theory of social perception. Psychological review, 90(3), p.215. 
McKinney, J. B. (2015). Effective financial management in public and nonprofit agencies.ABCCLIO.

Moloantoa, M. E., (2015). Factors affecting job satisfaction of academic employees: a case study of the National University of Lesotho (Doctoral dissertation).

Murphy, B. (2015). The impact of reward systems on employee performance (Doctoral dissertation, Dublin Business School).

Mugaa, L. G., Guyo, W., \& Odhiambo, R. (2018).Influence of Financial Reward on Employee Performance in Large Commercial Banks in Nairobi City County in Kenya. Journal of Human Resource \& Leadership, 2(2), 39-55.

Ojokuku, R. M. \& Sajuyigbe, A.S. (2009). Effect of pay satisfaction dimensions on job performance in selected tertiary institutions in Osun State, Nigeria. African Journal Institute and Development (AJID), pp.86-95.

Pea, R. D., Mills, M. I., Hoffert, E., Rosen, J. H., \& Dauber, K. (2014). U.S. Patent No. $8,645,832$. Washington, DC: U.S. Patent and Trademark Office.

Ryan, R. M. \& Deci, E.L., 2000. Intrinsic and extrinsic motivations: Classic definitions and new directions. Contemporary educational psychology, 25(1), pp.54-67.

Skinner, B.F. (1948). Superstition in the pigeon. Journal of experimental psychology, 38(2), p.168.

Sharma, U., Forlin, C. \& Loreman, T. (2008). Impact of training on pre service teachers' attitudes and concerns about inclusive education and sentiments about persons with disabilities. Disability \& Society, 23(7), pp.773-785. 